\title{
Monitoring Heavy Metal Contents with Sphagnum Junghuhnianum Moss Bags in Relation to Traffic Volume in Wuxi, China
}

\author{
Rong $\mathrm{Hu}^{\dagger}$, Yun Yan ${ }^{\dagger}$, Xiaoli Zhou, Yanan Wang and Yanming Fang * \\ Co-Innovation Center for Sustainable Forestry in Southern China, College of Biology and the Environment, \\ Nanjing Forestry University, Nanjing 210037, China; hurong809228@163.com (R.H.); \\ yanyun3100090@163.com (Y.Y.); zhouxiaoli0404@163.com (X.Z.); m13770762069@163.com (Y.W.) \\ * Correspondence: jwu4@njfu.edu.cn; Tel.: +86-25-8542-7428 \\ + Co-first authors to this study.
}

Received: 22 January 2018; Accepted: 16 February 2018; Published: 22 February 2018

\begin{abstract}
Despite its small size, a moss bag can reveal the different temporal and spatial deposition patterns of pollutants at a particular site; therefore, researchers can use moss bags to determine pollution sources and to put forward strategies for pollution control. Although the use of moss bags to monitor atmospheric pollution has been widely reported in Europe, there are few such empirical studies in China. Thus, in this study, bags containing the moss Sphagnum junghuhnianum were used to assess the concentrations of heavy metals (chromium $(\mathrm{Cr})$, copper $(\mathrm{Cu})$, lead $(\mathrm{Pb})$, vanadium $(\mathrm{V})$, and zinc $(\mathrm{Zn})$ ) at five sampling sites (four roads and a forest park) during the summer and winter of 2012. According to the relative accumulation factor (RAF) and contamination factor (CF) results, pollution in winter was heavier than that in summer, and $\mathrm{Cr}$ was found to be the most contaminating, having the highest mean CF. There was a significant positive correlation $(p<0.05)$ between traffic volume and concentration for three heavy metals $(\mathrm{Cr}, \mathrm{Cu}$, and $\mathrm{V})$ in winter, whereas a significant positive correlation $(p<0.05)$ was observed between traffic volume and concentrations for four heavy metal elements $(\mathrm{Cr}, \mathrm{Pb}, \mathrm{V}$, and $\mathrm{Zn})$ in summer, indicating a close relationship between heavy metal contents and traffic volume. Although there was substantial variation in the concentrations of the five heavy metals in the moss bags, significant correlations between heavy metals suggested that the contaminants originated from a common source, namely vehicle emissions. The results demonstrated that the four roads were subject to different degrees of pollution depending on the volume of traffic using each road. Therefore, the results of this study suggest that traffic volume is a major reason for heavy metal pollution.
\end{abstract}

Keywords: heavy metal; moss bag method; Sphagnum junghuhnianum

\section{Introduction}

Traffic pollution is one of the most important sources of environmental pollution in urban areas, especially when heavy industry is not present. Research shows that air pollution caused by traffic is becoming increasingly prominent, with soot-type pollution in some cities being replaced by pollution from motor vehicle emissions. The U.S. Environmental Protection Agency (EPA) investigated contaminants resulting from vehicle emissions, including heavy metals, such as $\mathrm{Cr}, \mathrm{Cu}, \mathrm{Pb}, \mathrm{V}$, and $\mathrm{Zn} \mathrm{[1],} \mathrm{and} \mathrm{found} \mathrm{a} \mathrm{direct} \mathrm{link} \mathrm{between} \mathrm{air} \mathrm{pollution} \mathrm{and} \mathrm{traffic} \mathrm{[2,3].} \mathrm{In} \mathrm{particular,} \mathrm{heavy}$ metal pollution results from motor vehicle exhaust emissions, secondary dust raised by vehicles, wear of tyres and other parts of vehicles, and corrosion [4-8]. Heavy metals are ingested via the respiratory or digestive tracts into the human body, causing serious harm to human health. Therefore, increasing research attention has been paid to heavy metal air pollution. However, existing air 
pollution monitoring methods are expensive and difficult to perform. As a result of its simple structure, strong adsorption capacity, and easy access compared with other biosorbents, mosses have a significantly higher concentration of surface groups that are able to bind such metals at the cell surface [9], which explains why they can be used to monitor such elements. Moss has also been used as an ideal biological indicator for atmospheric environmental monitoring. The use of moss bags to monitor environmental pollution originated in Europe, where it is now widely used, as reviewed by Onianwa [10]. The moss bag technique was originally introduced by Goodman and Roberts and later modified by Little and Martin. Goodman and Roberts [11] used Hypnum cupressiforme to monitor the concentration of $\mathrm{Zn}, \mathrm{Ni}, \mathrm{Pb}$, and $\mathrm{Cr}$ in an industrial area in southwest Wales, whereas Cameron and Nickless [12] used the moss bag method to monitor $\mathrm{Zn}, \mathrm{Pb}$, and $\mathrm{Cr}$ concentrations near a lead-zinc smelter in Britain. Moss bags have also been widely used to monitor atmospheric pollutants in many countries, including Finland [13-15], the USA [16], Bulgaria [17], Italy [18,19], the Slovak Republic [20], Poland [21], and Serbia [22-25]. The most influential of these was a 5-year European transnational joint monitoring program involving more than 100 scientists from 28 countries [2,26-28]. In China, use of the moss bag method to determine pollution levels has been documented in Shanghai [29], Chongqing [30], and Guizhou [31]. Moss bags can be used to monitor not only urban air pollution, but also air around volcanoes [32], tunnels [33], airports [34], and bodies of water [35].

Wuxi city is located at E119 $31^{\prime} \sim 120^{\circ} 36^{\prime}, \mathrm{N} 31^{\circ} 07^{\prime} \sim 32^{\circ} 02^{\prime}$ in southern Jiangsu Province, which covers an area of approximately $4628 \mathrm{~km}^{2}$. It has a typical subtropical humid climate, with a mean temperature of $1.2^{\circ} \mathrm{C}$ in January and $31.2^{\circ} \mathrm{C}$ in July, and a mean annual precipitation of $1121 \mathrm{~mm}$. Wuxi is an important industrial city located in the Yangtze River Delta. Along with rapid economic development in recent years, urban construction in Wuxi has also increased rapidly, as has motor vehicle ownership. The number of vehicles registered in the city had reached 573,000 by the end of 2011 , and will continue to increase at an annual rate of $15 \%$ according to local statistics.

Therefore, the objectives of the current study were to use moss bags to: (1) evaluate the degree of pollution of heavy metals $(\mathrm{Cr}, \mathrm{Cu}, \mathrm{Pb}, \mathrm{V}$, and $\mathrm{Zn}$ ) at four roads in Wuxi; (2) determine the difference in heavy metal concentrations between the winter (low temperatures and low rainfall) and the summer (high temperatures and high rainfall); (3) analyze the influence of traffic volume on the airborne concentration of heavy metals; and (4) analyze the relationships among the five heavy metal elements at each study site.

\section{Materials and Methods}

\subsection{Moss Sampling, Bag Preparation and Exposure}

Sphagnum junghuhnianum moss was collected from Longwangshan, Anji, Zhejiang Province. The moss is easy to identify. It is also easy to handle in the laboratory and has been used repeatedly in other biomonitoring studies with moss bags. Moss carpets were collected from the ground in open spaces, cleaned with water, and air-dried. Moss bags were prepared by weighing out $2 \mathrm{~g}$ of moss (air-dried weight) and packing it loosely in nylon nets of $18 \times 14 \mathrm{~cm}$ with a mesh size of $2 \mathrm{~mm}^{2}$.

The moss bags were set up at five study sites (Figure 1): one control site at Huishan National Forest Park (Huishan), and four at different roads (Minfeng, Fengbin, 312 National Road, and Tongjiang Avenue). Minfeng connects several residential districts, while Fengbin is located at the junction of Fengxiang Road with Xicheng Road. 312 National Road passes through Wuxi, and runs for $48.43 \mathrm{~km}$. Tongjiang Avenue is connected to the Shanghai-Nanjing and Xicheng Expressways, which are important roads for travel in and out of the city. There are no other sources of pollution around the four selected roads; thus, we could be certain that any heavy metal elements detected in the bags would result from traffic pollution rather than from other sources.

The moss bags were exposed to the air by hanging them approximately $3-4 \mathrm{~m}$ above the ground at the monitoring sites for 6 weeks [33]. Each bag was fully exposed to the air. Five bags were placed at each monitoring site (including the control site) and left in place for 6 weeks from 8 January to 
29 February 2012, and from 27 May to 8 July 2012 [36]. The moss bags were then taken to the laboratory for chemical analysis.

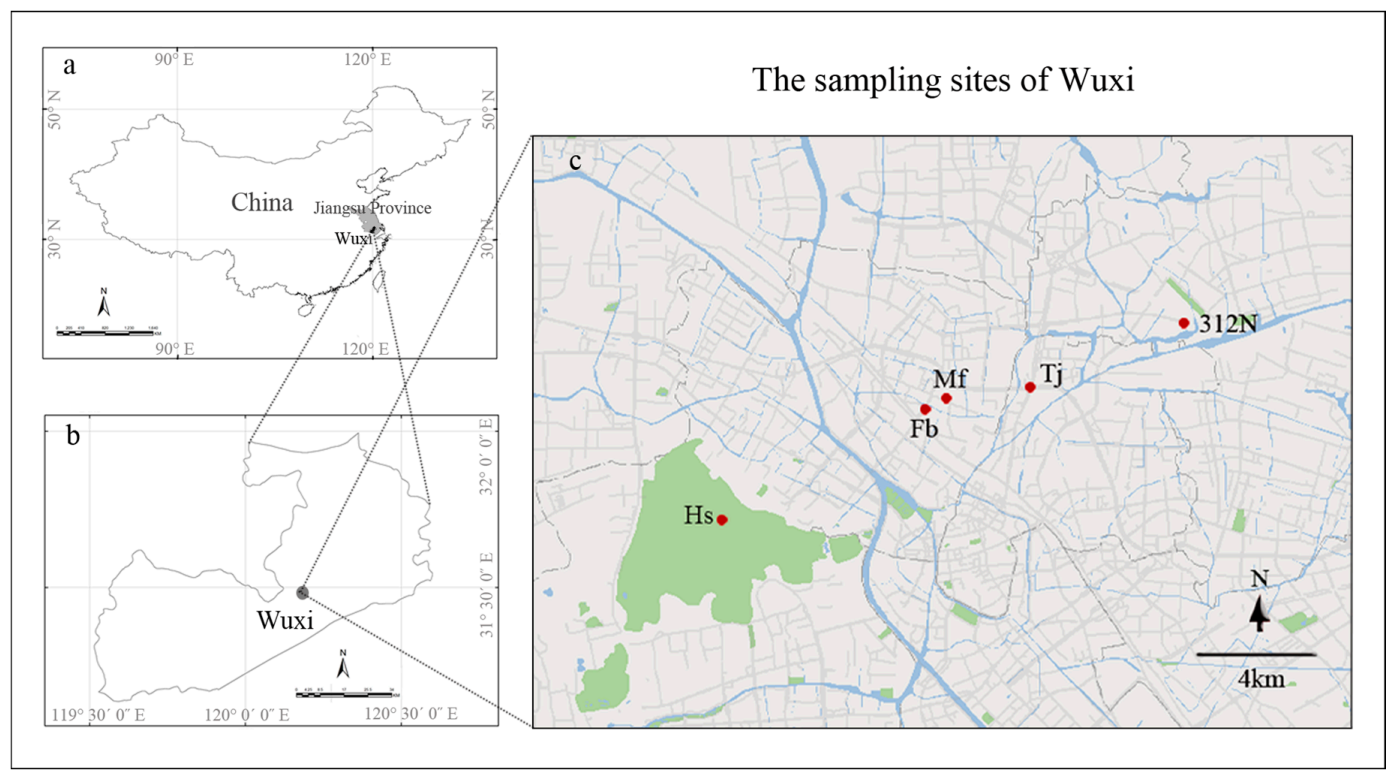

Figure 1. Location of Wuxi in China (a); location of study area in Wuxi (b); and a map of Wuxi showing the five monitoring sites: four roads (Mf: Minfeng Road, Fb: Fengbin Road, 312N: 312 National Road, Tj: Tongjiang Avenue) and a control site (Hs: Huishan) (c).

\subsection{Traffic Census}

The average daily traffic volume was determined at each of the four monitoring sites. Based on the midpoint of each road, six points at a distance of 100,200, and $300 \mathrm{~m}$ were selected on each side of each road. The number of cars passing each point was counted over 14 consecutive days ( $24 \mathrm{~h}$ a day), and the results were then averaged.

\subsection{Chemical Analysis}

Following exposure, the moss samples were removed from the nylon net and dried to a constant weight in a thermostat oven at $80^{\circ} \mathrm{C}$ for $12 \mathrm{~h}$, ground into powder, and kept in a clean, dry plastic bag. For chemical analysis, $0.5 \mathrm{~g}$ of the moss sample was digested in a solution of $\mathrm{HCLO}_{4}: \mathrm{HNO}_{3}=1: 4$ for approximately $12 \mathrm{~h}$. The filtered solution was then dried to a white powder on an electric iron plate. The powder was dissolved in distilled water up to $25 \mathrm{~mL}$ in a volumetric flask for chemical analysis. Two parallel samples were prepared for each moss sample. All concentrations were reported as mean values on a dry weight basis $\left(\mathrm{mg} \cdot \mathrm{kg}^{-1}\right)$.

The concentrations of five heavy metals $(\mathrm{Cr}, \mathrm{Cu}, \mathrm{Pb}, \mathrm{V}$, and $\mathrm{Zn})$ in each moss sample were determined by the Inductively Coupled Plasma-Atomic Emission Spectrometry (ICP-AES) (Perkin Elmer Corporation, Rodgau, Germany) method [37].

\subsection{Statistical Analysis}

To assess the accumulation of each heavy metal by S. junghuhnianum, relative accumulation factors (RAF) were calculated using Equation (1):

$$
\mathrm{RAF}=\left(\mathrm{C}_{\text {exposed }}-\mathrm{C}_{\text {initial }}\right) / \mathrm{C}_{\text {initial }}
$$

where $\mathrm{C}_{\text {exposed }}$ was the content of each element after exposure and $\mathrm{C}_{\text {initial }}$ was the content before exposure. 
Contaminations factors (CF), used to assess the degree of anthropogenic influence, were calculated using Equation (2):

$$
\mathrm{CF}=\mathrm{C}_{\text {moss }} / \mathrm{C}_{\text {background }}
$$

where $C_{\text {moss }}$ is the content of the element in the moss samples after exposure, and $C_{\text {background }}$ is the content of the same element determined before exposure. The scale for $\mathrm{CF}$ categories proposed by Ma et al. [38] was applied in the present study. This comprises five categories: (1) C1: CF $\leq 1.2$, no contamination; (2) C2: $1.2<\mathrm{CF} \leq 2.2$, slight contamination; (3) $\mathrm{C} 3: 2.2<\mathrm{CF} \leq 3.3$, moderate contamination; (4) C4: $3.3<\mathrm{CF} \leq 4.3$, severe contamination; (5) $\mathrm{C} 5: \mathrm{CF}>4.3$, extreme contamination.

The correlations between the concentrations of $\mathrm{Cr}, \mathrm{Cu}, \mathrm{Pb}, \mathrm{V}$, and $\mathrm{Zn}$ in the moss and traffic volume were analyzed by the correlative analysis method using SPSS 17.0 (IBM Corporation, Somers, NY, USA). The statistical significance was based on 0.05 .

\section{Results and Discussion}

\subsection{Concentrations of $\mathrm{Cr}, \mathrm{Cu}, \mathrm{Pb}, \mathrm{V}$, and $\mathrm{Zn}$ in Moss before and after Exposure}

The average concentrations of $\mathrm{Cr}, \mathrm{Cu}, \mathrm{Pb}, \mathrm{V}$, and $\mathrm{Zn}$ in moss bags after 6 weeks of exposure (Table 1) were used to compare the levels of atmospheric pollution at the different sample sites. The concentrations of all elements in the exposed moss bags were higher than the initial concentrations. As shown in Table 1, in the winter, following 6 weeks of exposure, the concentrations of $\mathrm{Cr}$ were $2.55-8.4 \mathrm{mg} \cdot \mathrm{kg}^{-1}$ similarly, the concentrations of $\mathrm{Cu}, \mathrm{Pb}, \mathrm{V}$, and $\mathrm{Zn}$ were $7.83-16,30.05-39.58,1.68-4.03$, and $94.78-146.7 \mathrm{mg} \cdot \mathrm{kg}^{-1}$, respectively. Moss sample analyses revealed a concentration of $\mathrm{Cr}$ in the range of 3.0-8.75 mg $\mathrm{kg}^{-1}$ following exposure during the summer, with markedly different concentrations of $\mathrm{Cu}, \mathrm{Pb}, \mathrm{V}$, and $\mathrm{Zn}\left(6.84-16.3,19.85-31.65,1.98-5.03\right.$, and 74.55-142.1 $\mathrm{mg}^{\mathrm{kg}}{ }^{-1}$, respectively). In general, an increasing level of pollution is observed from Huishan to Minfeng, Fengbin, 312 National Road, and Tongjiang Avenue (Figure 2). Therefore, according to the mean metal concentrations reported in Table 1, Tongjiang Avenue was the most polluted site, with the highest values for all elements, except for $\mathrm{Zn}$ recorded in winter in 312 National Road (146.7 versus 127.63). Moreover, it is worth noting that the control site Huishan had a pollution level that was comparable to Minfeng Road for $\mathrm{Pb}, \mathrm{V}$, and $\mathrm{Zn}$. This unexpected result could depend on the long-range transport of heavy metals [39].

Table 1. The concentration of metals ( $\mathrm{mg} \cdot \mathrm{kg}^{-1}$, dry weight) in the moss bags over 6 weeks during the winter and summer.

\begin{tabular}{|c|c|c|c|c|c|c|c|c|c|c|}
\hline \multirow{2}{*}{ Parameter } & \multicolumn{2}{|c|}{$\mathrm{Cr}$} & \multicolumn{2}{|c|}{$\mathrm{Cu}$} & \multicolumn{2}{|c|}{$\mathbf{P b}$} & \multicolumn{2}{|c|}{$\mathbf{V}$} & \multicolumn{2}{|c|}{$\mathrm{Zn}$} \\
\hline & Winter & Summer & Winter & Summer & Winter & Summer & Winter & Summer & Winter & Summer \\
\hline Initial & 1.93 & 2.78 & 5.35 & 5.15 & 20.0 & 17.85 & 1.08 & 1.83 & 63.05 & 64.55 \\
\hline $\mathrm{SD}$ & 0.18 & 0.81 & 0.07 & 0.21 & 0.57 & 1.34 & 0.04 & 0.18 & 0.99 & 1.63 \\
\hline \multicolumn{11}{|l|}{ Huishan } \\
\hline Mean & 2.55 & 3.0 & 7.83 & 6.84 & 30.05 & 19.85 & 1.68 & 1.98 & 94.78 & 85.55 \\
\hline SD & 0.21 & 0.07 & 0.67 & 0.35 & 2.83 & 0.07 & 0.11 & 0.04 & 7.60 & 1.06 \\
\hline RAF & 0.32 & 0.08 & 0.46 & 0.33 & 0.50 & 0.11 & 0.56 & 0.08 & 0.50 & 0.33 \\
\hline \multicolumn{11}{|l|}{ Minfeng Road } \\
\hline Mean & 3.03 & 4.85 & 9.45 & 8.88 & 30.75 & 20.3 & 1.53 & 2.4 & 98.3 & 74.55 \\
\hline SD & 0.74 & 0.07 & 1.84 & 0.81 & 0.21 & 0.07 & 0.32 & 0.14 & 0.28 & 3.75 \\
\hline RAF & 0.57 & 0.75 & 0.77 & 0.72 & 0.54 & 0.14 & 0.42 & 0.32 & 0.56 & 0.16 \\
\hline $\mathrm{CF}$ & 1.19 & 1.62 & 1.21 & 1.30 & 1.02 & 1.02 & 0.91 & 1.22 & 1.04 & 0.87 \\
\hline \multicolumn{11}{|l|}{ Fengbin Road } \\
\hline Mean & 4.43 & 5.35 & 10.58 & 10.75 & 39.58 & 21.28 & 2.43 & 2.68 & 100.63 & 87.28 \\
\hline SD & 0.11 & 0.21 & 0.32 & 1.20 & 1.87 & 2.79 & 0.18 & 0.39 & 1.24 & 2.79 \\
\hline RAF & 1.30 & 0.93 & 0.98 & 1.09 & 0.98 & 0.19 & 1.26 & 0.47 & 0.60 & 0.35 \\
\hline $\mathrm{CF}$ & 1.74 & 1.78 & 1.35 & 1.57 & 1.32 & 1.07 & 1.45 & 1.35 & 1.06 & 1.02 \\
\hline \multicolumn{11}{|l|}{312 National } \\
\hline Mean & 7.78 & 7.73 & 13.75 & 9.9 & 32.45 & 24.13 & 3.75 & 4.03 & 146.7 & 102.48 \\
\hline SD & 1.03 & 0.88 & 0.85 & 1.56 & 3.32 & 0.04 & 0.35 & 0.88 & 11.6 & 24.01 \\
\hline RAF & 3.04 & 1.78 & 1.57 & 0.92 & 0.62 & 0.35 & 2.49 & 1.21 & 1.33 & 0.59 \\
\hline $\mathrm{CF}$ & 3.05 & 2.58 & 1.76 & 1.45 & 1.08 & 1.22 & 2.24 & 2.04 & 1.55 & 1.20 \\
\hline
\end{tabular}


Table 1. Cont.

\begin{tabular}{|c|c|c|c|c|c|c|c|c|c|c|}
\hline \multirow{2}{*}{ Parameter } & \multicolumn{2}{|c|}{$\mathrm{Cr}$} & \multicolumn{2}{|c|}{$\mathrm{Cu}$} & \multicolumn{2}{|c|}{$\mathrm{Pb}$} & \multicolumn{2}{|c|}{$\mathbf{V}$} & \multicolumn{2}{|c|}{$\mathrm{Zn}$} \\
\hline & Winter & Summer & Winter & Summer & Winter & Summer & Winter & Summer & Winter & Summer \\
\hline \multicolumn{11}{|c|}{ Tongjiang Avenue } \\
\hline Mean & 8.4 & 8.75 & 16 & 16.3 & 33.8 & 31.65 & 4.03 & 5.03 & 127.63 & 142.1 \\
\hline $\mathrm{SD}$ & 0.14 & 0.07 & 0.21 & 1.20 & 0.92 & 0.07 & 0.11 & 0.11 & 3.22 & 14.71 \\
\hline RAF & 3.36 & 2.15 & 1.99 & 2.17 & 0.69 & 0.77 & 2.74 & 1.75 & 1.02 & 1.20 \\
\hline $\mathrm{CF}$ & 3.29 & 2.92 & 2.05 & 2.39 & 1.13 & 1.59 & 2.40 & 2.54 & 1.35 & 1.66 \\
\hline $\mathrm{RAF}_{\text {mean }}$ & 1.72 & 1.14 & 1.15 & 1.05 & 0.67 & 0.31 & 1.49 & 0.76 & 0.80 & 0.52 \\
\hline $\mathrm{CF}_{\text {mean }}$ & 2.32 & 2.22 & 1.59 & 1.68 & 1.14 & 1.23 & 1.75 & 1.79 & 1.25 & 1.19 \\
\hline
\end{tabular}

Mean: average value; $\mathrm{SD}$ : standard deviation; $\mathrm{RAF}_{\text {mean }}=$ relative accumulation factor $(\mathrm{RAF}) ; \mathrm{CF}_{\text {mean }}=\mathrm{contamination}$ factor $(\mathrm{CF})$.

The mean concentrations after 6 weeks of exposure and net increases over the winter and summer at the five different sampling sites are shown in Figures 2 and 3. Compared with the initial content, the concentration of $\mathrm{Zn}$ varied widely. In addition, the highest concentrations of $\mathrm{Cr}, \mathrm{Cu}, \mathrm{Pb}, \mathrm{V}$, and $\mathrm{Zn}$ were recorded on Tongjiang Avenue during the summer, the high concentrations of $\mathrm{Cr}, \mathrm{Cu}$, and $\mathrm{V}$ occurred on Tongjiang Avenue during the winter, and the highest concentrations of $\mathrm{Pb}$ and $\mathrm{Zn}$ during the winter were recorded in Minfeng and 312 National Road, respectively. The lowest values of $\mathrm{Cr}, \mathrm{Cu}, \mathrm{Pb}, \mathrm{V}$, and $\mathrm{Zn}$ were recorded in Minfeng during both winter and summer. Tongjiang Avenue is an important traffic thoroughfare with a large vehicle flow, followed by 312 National Road and Fengbin. Therefore, the pollution of Tongjiang Avenue is the most serious. By contrast, Minfeng connects several residential areas with a relatively small traffic volume and relatively slight contamination. The concentrations of elements in the moss bags were higher than those in the control site, indicating that they were all polluted by different levels of heavy metals. The degree of pollution was as follows (in descending order): Tongjiang Avenue, 312 National Road, Fengbin, Minfeng, and Huishan (Figure 2). These findings support the hypothesis that vehicles are the main source of these metals. The highest concentration of metals in the moss bags was of $\mathrm{Zn}$, followed by $\mathrm{Pb}, \mathrm{Cu}, \mathrm{Cr}$, and $\mathrm{V}$ (Figure 2).
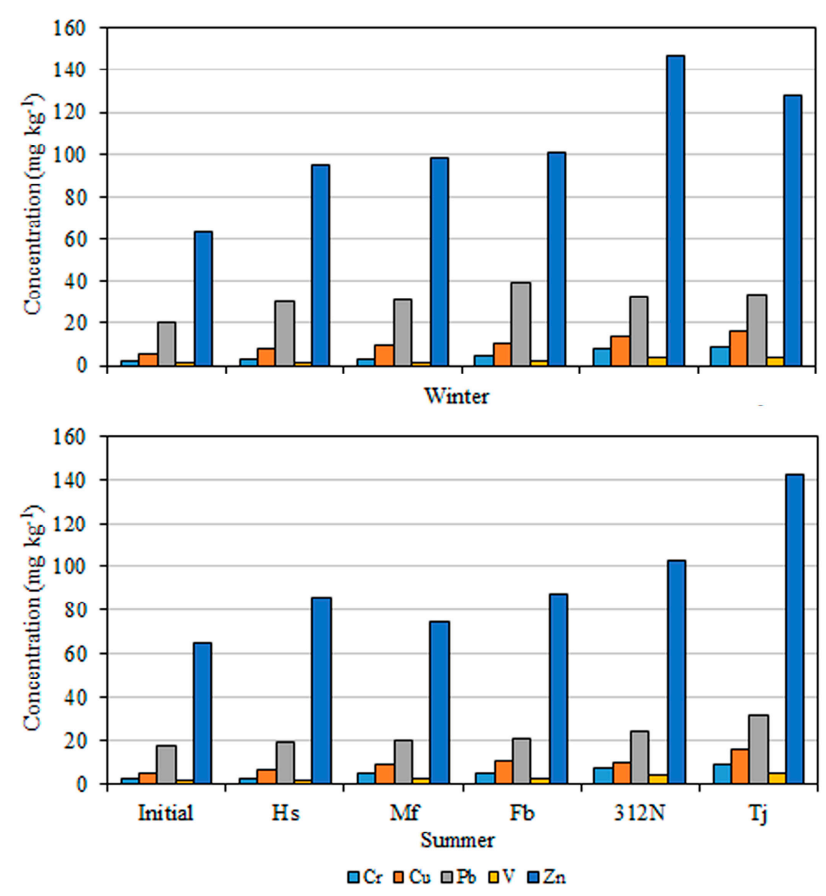

Figure 2. Average concentration of elements $\left(\mathrm{mg} \cdot \mathrm{kg}^{-1}\right)$ in Sphagnum junghuhnianum exposed to air in bags for 6 weeks at Huishan (Hs), Minfeng Road (Mf), Fengbin Road (Fb), 312 National Road (312N), and Tongjiang Road (Tj). 


\subsection{Relative Accumulation Factors and Contamination Factors of Metals in the Moss Samples}

\subsubsection{Relative Accumulation Factors}

Table 1 presents the RAFs of the metals in the S. junghuhnianum moss samples at the five monitoring sites after 6 weeks exposure. An RAF avoids the effect of the initial element concentration on the final concentration, and has been previously used to compare the accumulation of metals by different monitoring species [9]. During the winter monitoring period, the average RAFs of the heavy metals were $\mathrm{Cr}: 1.72, \mathrm{Cu}: 1.15, \mathrm{~Pb}: 0.67, \mathrm{~V}: 1.49$, and $\mathrm{Zn}: 0.80$. Thus, the most-accumulated element in the moss bags was $\mathrm{Cr}$, followed by $\mathrm{V}>\mathrm{Cu}>\mathrm{Zn}>\mathrm{Pb}$. During the summer monitoring period, the average RAFs were $\mathrm{Cr}: 1.14, \mathrm{Cu}: 1.05, \mathrm{~Pb}: 0.31, \mathrm{~V}: 0.76$, and $\mathrm{Zn}: 0.52$, resulting in the order $\mathrm{Cr}>\mathrm{Cu}>\mathrm{V}$ $>\mathrm{Zn}>\mathrm{Pb}$. It can be seen from Figure 3 that the average RAFs of the five heavy metal elements in the winter were higher than those in the summer, indicating that air pollution is more serious in the winter than in the summer. Previous studies have reported that the amount of metal that accumulates in moss bags is related to the associated weather conditions [40]. At the study site, there is less precipitation during the winter compared with the summer and, therefore, pollutants in the atmosphere are less likely to be washed out of the atmosphere, to settle on and be absorbed by vegetation, with the reverse being true in the summer. Consequently, the summer pollution is lighter than in the winter due to more precipitation in summer than in winter.

In previous studies, an RAF higher than 0.5 indicated a slight elemental enrichment in moss, and values $>1$ indicated considerable elemental enrichment [33,41]. In the current study, the RAF indicated $\mathrm{Cr}, \mathrm{Cu}$, and $\mathrm{V}$ to be the most abundant elements in the moss exposed to air within the studied roads.

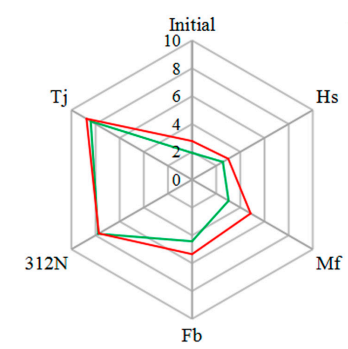

$\mathrm{Cr}$
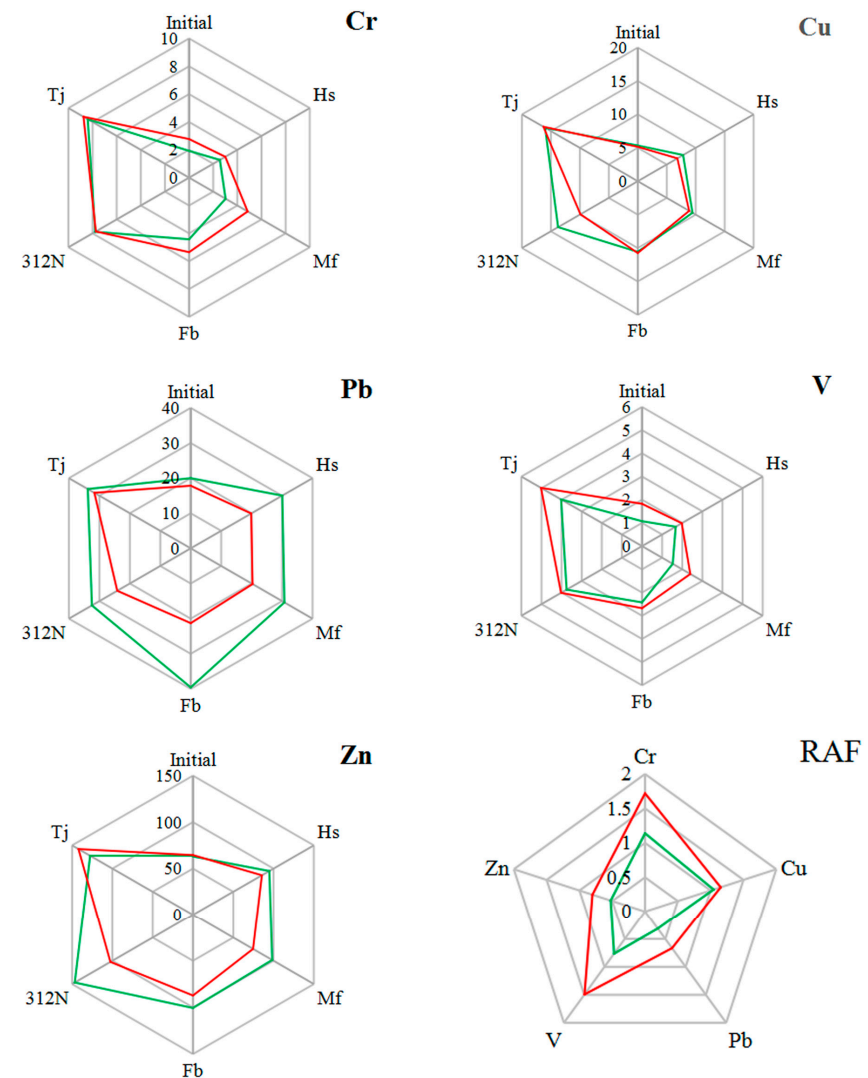

- winter — summer

Figure 3. Seasonal variation in metal concentrations $\left(\mathrm{mg} \cdot \mathrm{kg}^{-1}\right)$ in the moss S. junghuhnianum exposed to air in bags for 6 weeks at five monitoring sites as indicated by the average relative accumulation factor (RAF) for each metal in winter and summer. 


\subsubsection{Analysis of Contamination Factors and Pollution Levels}

The results of the CF analysis are given in Table 1. During the winter, the mean CFs were Cr: 2.32, $\mathrm{Cu}: 1.59, \mathrm{~Pb}: 1.14, \mathrm{~V}: 1.75$, and $\mathrm{Zn}: 1.25$, indicating the order of the heavy metals in terms of average $\mathrm{CF}$ across the monitoring sites to be: $\mathrm{Cr}>\mathrm{Cu}>\mathrm{V}>\mathrm{Zn}>\mathrm{Pb}$. During the summer, the CFs were $\mathrm{Cr}: 2.22$, $\mathrm{Cu}: 1.68, \mathrm{~Pb}: 1.23, \mathrm{~V}: 1.79$, and $\mathrm{Zn}: 1.19$, indicating the order of the heavy metals in terms of average $\mathrm{CF}$ across the monitoring sites to be: $\mathrm{Cr}>\mathrm{V}>\mathrm{Cu}>\mathrm{Pb}>\mathrm{Zn}$. Thus, in both monitoring periods, $\mathrm{Cr}$ has the highest $C F$, indicating that atmospheric pollution with $\mathrm{Cr}$ to be the most serious of all metals investigated and, thus, requiring the most urgent attention.

Based on the CF results, pollution levels are shown in Table 2. The monitoring sites were characterized by three categories of contamination scales: $\mathrm{C} 1, \mathrm{C} 2$, and $\mathrm{C} 3$, described as no pollution, slight pollution, and moderate pollution, respectively. During the winter, the levels of $\mathrm{Cr}, \mathrm{Pb}, \mathrm{V}$, and $\mathrm{Zn}$ in Minfeng indicated no pollution, whereas those of $\mathrm{Cu}$ indicated only slight pollution; by contrast, the levels of $\mathrm{Cr}, \mathrm{Cu}, \mathrm{Pb}$, and $\mathrm{V}$ in Fengbin indicated slight pollution, whereas those of $\mathrm{Zn}$ indicated no pollution. The level of $\mathrm{Cr}$ and $\mathrm{V}$ in 312 National Road indicated moderate pollution, those of $\mathrm{Cu}$ and $\mathrm{Zn}$ indicated slight pollution, and that of $\mathrm{Pb}$ indicated no pollution; the level of pollution at Tongjiang Avenue was similar to that of 312 National Road. During the summer, the levels of $\mathrm{Cr}, \mathrm{Cu}$, and $\mathrm{V}$ in Minfeng indicated slight pollution, whereas those of $\mathrm{Pb}$ and $\mathrm{Zn}$ indicated no pollution; the Fengbin pollution level was consistent with that of Minfeng. By contrast, the level of $\mathrm{Cu}, \mathrm{Pb}$, and $\mathrm{V}$ in 312 National Road indicated slight pollution, that of $\mathrm{Cr}$ indicated moderate pollution, and that of $\mathrm{Zn}$ indicated no pollution. Finally, the level of $\mathrm{Cr}, \mathrm{Cu}$, and $\mathrm{V}$ in Tongjiang Avenue indicated moderate pollution, whereas those of $\mathrm{Pb}$ and $\mathrm{Zn}$ indicated slight pollution. In summary, the $\mathrm{CF}$ values for heavy metals were higher compared with other roads, except for $\mathrm{Zn}$ in winter in 312 National Road (1.55 versus 1.35), and the differences in CF values suggest a high risk of heavy metal contamination in Tongjiang Avenue.

Table 2. The contamination factors (CFs) and contamination classification.

\begin{tabular}{|c|c|c|c|c|c|c|c|c|c|c|}
\hline \multirow{2}{*}{ Parameter } & \multicolumn{2}{|c|}{$\mathrm{Cr}$} & \multicolumn{2}{|c|}{$\mathrm{Cu}$} & \multicolumn{2}{|c|}{$\mathbf{P b}$} & \multicolumn{2}{|c|}{ V } & \multicolumn{2}{|c|}{$\mathrm{Zn}$} \\
\hline & Winter & Summer & Winter & Summer & Winter & Summer & Winter & Summer & Winter & Summer \\
\hline \multicolumn{11}{|l|}{ Minfeng Road } \\
\hline $\mathrm{CF}$ & 1.19 & 1.62 & 1.21 & 1.30 & 1.02 & 1.02 & 0.91 & 1.22 & 1.04 & 0.87 \\
\hline Classification & $\mathrm{C} 1$ & $\mathrm{C} 2$ & $\mathrm{C} 2$ & C2 & $\mathrm{C} 1$ & $\mathrm{C} 1$ & $\mathrm{C} 1$ & $\mathrm{C} 2$ & $\mathrm{C} 1$ & $\mathrm{C} 1$ \\
\hline Contamination & $\mathrm{N}$ & $\mathrm{S}$ & $\mathrm{S}$ & $\mathrm{S}$ & $\mathrm{N}$ & $\mathrm{N}$ & $\mathrm{N}$ & $\mathrm{S}$ & $\mathrm{N}$ & $\mathrm{N}$ \\
\hline \multicolumn{11}{|l|}{ Fengbin Road } \\
\hline CF & 1.74 & 1.78 & 1.35 & 1.57 & 1.32 & 1.07 & 1.45 & 1.35 & 1.06 & 1.02 \\
\hline Classification & $\mathrm{C} 2$ & $\mathrm{C} 2$ & $\mathrm{C} 2$ & $\mathrm{C} 2$ & $\mathrm{C} 2$ & $\mathrm{C} 1$ & $\mathrm{C} 2$ & $\mathrm{C} 2$ & $\mathrm{C} 1$ & $\mathrm{C} 1$ \\
\hline Contamination & $\mathrm{S}$ & $\mathrm{S}$ & $\mathrm{S}$ & $\mathrm{S}$ & $\mathrm{S}$ & $\mathrm{N}$ & $\mathrm{S}$ & $\mathrm{S}$ & $\mathrm{N}$ & $\mathrm{N}$ \\
\hline \multicolumn{11}{|l|}{312 National } \\
\hline \multicolumn{11}{|l|}{ Road } \\
\hline CF & 3.05 & 2.58 & 1.76 & 1.45 & 1.08 & 1.22 & 2.24 & 2.04 & 1.55 & 1.20 \\
\hline Classification & $\mathrm{C} 3$ & $\mathrm{C} 3$ & $\mathrm{C} 2$ & $\mathrm{C} 2$ & $\mathrm{C} 1$ & $\mathrm{C} 2$ & $\mathrm{C} 3$ & $\mathrm{C} 2$ & $\mathrm{C} 2$ & $\mathrm{C} 1$ \\
\hline Contamination & $\mathrm{M}$ & $\mathrm{M}$ & $\mathrm{S}$ & $\mathrm{S}$ & $\mathrm{N}$ & $\mathrm{S}$ & $\mathrm{M}$ & $\mathrm{S}$ & $\mathrm{S}$ & $\mathrm{N}$ \\
\hline \multicolumn{11}{|l|}{ Tongjiang } \\
\hline \multicolumn{11}{|l|}{ Avenue } \\
\hline CF & 3.29 & 2.92 & 2.05 & 2.39 & 1.13 & 1.59 & 2.40 & 2.54 & 1.35 & 1.66 \\
\hline Classification & $\mathrm{C} 3$ & $\mathrm{C} 3$ & $\mathrm{C} 2$ & $\mathrm{C} 3$ & $\mathrm{C} 1$ & $\mathrm{C} 2$ & $\mathrm{C} 3$ & $\mathrm{C} 3$ & $\mathrm{C} 2$ & $\mathrm{C} 2$ \\
\hline Contamination & $\mathrm{M}$ & $\mathrm{M}$ & $\mathrm{S}$ & $\mathrm{M}$ & $\mathrm{N}$ & $\mathrm{S}$ & $\mathrm{M}$ & $\mathrm{M}$ & $\mathrm{s}$ & $\mathrm{s}$ \\
\hline
\end{tabular}

\subsection{Correlation Analysis between Metal Concentrations and Traffic Volume}

Traffic volume statistics are shown in Figure 4. The traffic volume order was: Tongjiang Avenue $(26,310) \geq 312$ National Road $(17,490) \geq$ Fengbin $(8730) \geq$ Minfeng $(4345)$, whereas the order of the study sites in terms of average heavy metal concentration was: Tongjiang Avenue $\geq 312$ National Road $\geq$ Fengbin $\geq$ Minfeng $\geq$ Huishan, indicating that the heavy metal content in the moss bag was positively correlated with the traffic volume; that is, the higher the traffic volume, the higher 
the heavy metal content and the more serious the level of pollution. Huishan is a scenic spot, far away from traffic pollution; thus, it was unsurprising that it had the lowest concentration of heavy metals. Guttormsen [42] reported that an average daily traffic volume of 12,000 vehicles on both sides of a road resulted in serious levels of pollution within $20 \mathrm{~m}$ of that road. In this study, the average daily traffic volume of 312 National Road and Tongjiang Avenue was 17,490 and 26,310 vehicles, respectively. Thus, the levels of heavy metal pollution at these sites were the most serious. The pollution source from vehicle movements can be summarized as [23]: (1) exhaust emissions from the tailpipe; (2) non-exhaust emissions due to the wear and tear of vehicle parts, such as brakes, tyres, and clutch; and (3) resuspension of road dust. In previous studies, traffic emissions mainly contributed to increased concentrations of $\mathrm{Cr}, \mathrm{Cu}, \mathrm{Pb}, \mathrm{V}$, and $\mathrm{Zn}$, whereas fuel combustion (known as "exhaust emissions") was the major source of $\mathrm{Cr}, \mathrm{Cu}$, and $\mathrm{V}$ emissions [43]. Pb could originate from brake-wear-related emissions [44]. In addition, tire abrasion emissions and fuel combustion have been recognized as important sources of $\mathrm{Zn}[45]$.

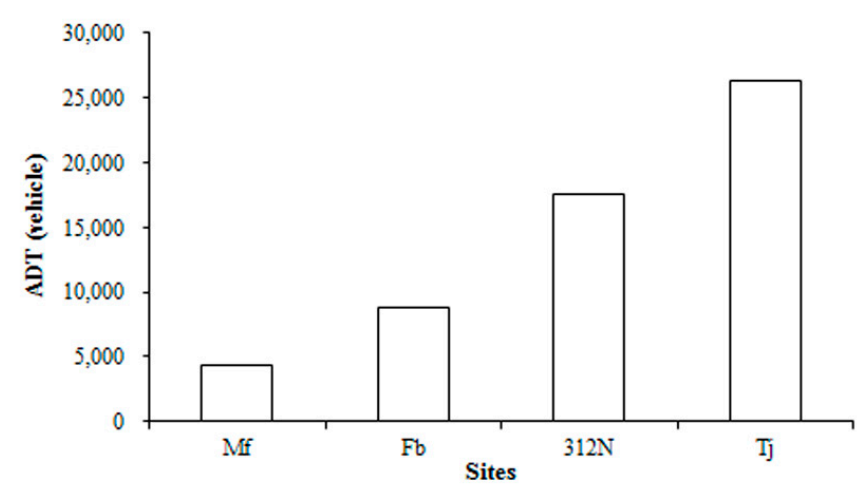

Figure 4. Traffic statistics for each of the study sites (Mf: Minfeng Road, Fb: Fengbin Road, 312N: 312 National Road, Tj: Tongjiang Avenue) ADT: average daily traffic volume.

The results of the correlation analysis between heavy metal concentration and average daily traffic volume are provided in Table 3. There was a significant positive correlation $(p<0.05)$ between the concentrations of $\mathrm{Cr}, \mathrm{Cu}$, and $\mathrm{V}$ and average daily traffic volume during the winter, but not between $\mathrm{Zn}$ and $\mathrm{Pb}$ and the average daily traffic volume. During the summer, there was a significant positive correlation $(p<0.05)$ between $\mathrm{Cr}, \mathrm{Pb}, \mathrm{V}$, and $\mathrm{Zn}$ and average daily traffic volume. This result does not completely agree with the literature in fact, in a previous study [46], the authors found a significant correlation between tyre-wear $\mathrm{Zn}$ emission and daily traffic volume, but the $\mathrm{Zn}$ level was 1000-fold higher than that of $\mathrm{Cu}$, whereas in this study $\mathrm{Zn}$ concentration was about 10-20-fold higher than $\mathrm{Cu}$. There was a negative correlation between $\mathrm{Pb}$ and average daily traffic volume in winter; this could be related to the long residence time of $\mathrm{Pb}$ in the atmosphere. There was in general a significant correlation between the concentration of heavy metals and the average daily traffic volume, indicating that traffic volume has a direct impact on heavy metal concentrations.

Table 3. Correlation analysis between the concentration of heavy metals and traffic volume.

\begin{tabular}{cccccc}
\hline \multicolumn{7}{c}{ Pearson Correlation } & & \\
\hline & $\mathbf{C r}$ & $\mathbf{C u}$ & $\mathbf{P b}$ & $\mathbf{V}$ & $\mathbf{Z n}$ \\
\hline ADT in winter & $0.964^{*}$ & $0.998^{*}$ & -0.068 & $0.956^{*}$ & 0.750 \\
ADT in summer & $0.981 *$ & 0.863 & $0.964^{*}$ & $0.993 *$ & $0.982 *$ \\
\hline
\end{tabular}

ADT: Average daily traffic volume * Correlation is significant at the 0.05 level. 


\subsection{Correlation Analysis between Metal Elements}

The Pearson's correlation coefficients of heavy metals in the five monitoring sites are summarized in Figure 5. During the winter, the correlation coefficients were higher than 0.960 for $\mathrm{Cu}-\mathrm{Cr}$, V-Cr, and $\mathrm{V}-\mathrm{Cu}$, and were between 0.906 and 0.913 for $\mathrm{Zn}-\mathrm{Cr}, \mathrm{Zn}-\mathrm{Cu}$, and $\mathrm{Zn}-\mathrm{V}$. During the summer, the correlation coefficients were higher than 0.920 for $\mathrm{Pb}-\mathrm{Cu}, \mathrm{V}-\mathrm{Cr}, \mathrm{V}-\mathrm{Pb}, \mathrm{Zn}-\mathrm{Cu}, \mathrm{Zn}-\mathrm{Pb}$, and $\mathrm{Zn}-\mathrm{V}$, and between 0.871 and 0.906 for $\mathrm{Cu}-\mathrm{Cr}, \mathrm{Pb}-\mathrm{Cr}, \mathrm{V}-\mathrm{Cr}$, and $\mathrm{Zn}-\mathrm{Cr}$. The very high coefficients between these pairs of elements suggest that they had a common source, namely from automobile exhausts, vehicle parts, tyre wear and tear, and friction release when braking. There was no significant correlation between $\mathrm{Pb}$ and all of the other elements in winter. This could be related to the deposition of $\mathrm{Pb}$ as a result of its physicochemical characteristics, which result in a long residence time in the atmosphere.

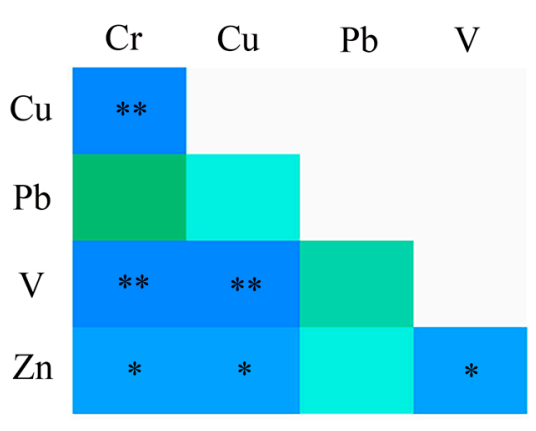

winter

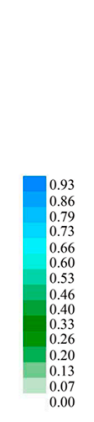

$\mathrm{Zn}$

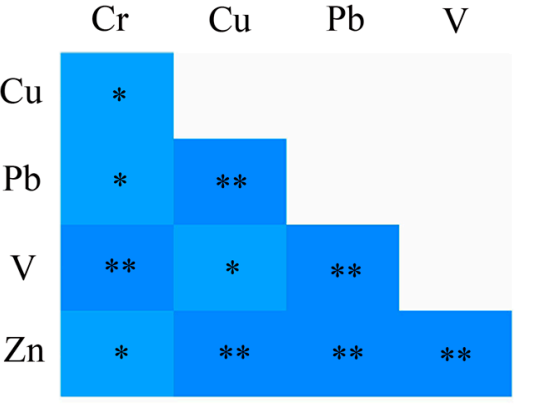

summer

Figure 5. Pearson correlation coefficient matrix between heavy metals in moss bags in winter and summer. ${ }^{*}$ Correlation significant at the 0.05 level; ${ }^{* *}$ Correlation significant at the 0.01 level.

\section{Conclusions}

In this study, heavy metals accumulated in S. junghuhnianum moss bags were exposed to air for 6 weeks at different sites across Wuxi city. Higher concentrations of metals were recorded in moss bags placed in Tongjiang Avenue. The RAF generally showed that pollution was heavier in winter than in summer. Significant correlations were found between metal concentrations and traffic volume in winter $(\mathrm{Cr}, \mathrm{Cu}, \mathrm{V}, \mathrm{Zn})$ and summer $(\mathrm{Cr}, \mathrm{Pb}, \mathrm{V}, \mathrm{Zn})$. The correlation between the different heavy metals showed that they had a common source: traffic pollution. The $\mathrm{CF}$ for $\mathrm{Cr}$ in the moss bags was the highest, indicating that $\mathrm{Cr}$ is the most serious pollutant. The concentrations of metals in S. junghuhnianum significantly reflected the degree of atmospheric pollution. Thus, the moss bag monitoring technique can be used to monitor heavy metal pollution in urban areas. However, using uniformly cloned mosses could result in more accurate survey data that can be compared across studies [19,47].

Acknowledgments: This study was supported by the Priority Academic Program Development of Jiangsu High Education Institutions (PAPD).

Author Contributions: Rong Hu wrote the manuscript and analyzed and interpreted the data. Yun Yan initialized the study and designed and performed the experiments. Xiaoli Zhou and Yanan Wang gave valuable advice on data interpretation. Yanming Fang helped to initiate the study and provided instructive advice and useful suggestions on this manuscript. All the authors have reviewed and approved the final version of the manuscript.

Conflicts of Interest: The authors declare no conflict of interests. 


\section{References}

1. Zechmeister, H.G.; Hohenwallner, D.; Riss, A.; Hanus-Illar, A. Estimation of element deposition derived from road traffic sources by using mosses. Environ. Pollut. 2005, 138, 238-249. [CrossRef] [PubMed]

2. Harmens, H.; Norris, D.A.; Steinnes, E.; Kubin, E.; Piispanen, J.; Alber, R.; Aleksiayenak, Y.; Blum, O.; Coskun, M.; Dam, M.; et al. Mosses as biomonitors of atmospheric heavy metal deposition: Spatial patterns and temporal trends in Europe. Environ. Pollut. 2010, 158, 3144-3156. [CrossRef] [PubMed]

3. Ewen, C.; Anagnostopoulou, M.A.; Ward, N.I. Monitoring of heavy metal levels in roadside dusts of Thessaloniki, Greece in relation to motor vehicle traffic density and flow. Environ. Monit. Assess. 2009, 157, 483-498. [CrossRef] [PubMed]

4. Guo, G.; Lei, M.; Chen, T.; Song, B.; Xiaoyan, L.I. Effect of road traffic on heavy metals in road dusts and roadside soils. Acta Sci. Circum. 2008, 28, 1937-1945.

5. Harrison, R.M.; Tilling, R.; Romero, M.S.C.; Harrad, S.; Jarvis, K. A study of trace metals and polycyclic aromatic hydrocarbons in the roadside environment. Atmos. Environ. 2003, 37, 2391-2402. [CrossRef]

6. Kemp, K. Trends and sources for heavy metals in urban atmosphere. Nucl. Instrum. Methods Phys. Res. 2002, 189, 227-232. [CrossRef]

7. Pal, S.K.; Wallis, S.G.; Arthur, S. Assessment of heavy metals emission from traffic on road surfaces. Cent. Eur. J. Chem. 2011, 9, 314-319. [CrossRef]

8. Sutherland, R.A.; Tack, F.M.G.; Ziegler, A.D. Road-deposited sediments in an urban environment: A first look at sequentially extracted element loads in grain size fractions. J. Hazard. Mater. 2012, 225, 54-62. [CrossRef] [PubMed]

9. Adamo, P.; Giordan, S.; Vingiani, S.; Cobianchi, R.C.; Violante, P. Trace element accumulation by moss and lichen exposed in bags in the city of Naples (Italy). Environ. Pollut. 2003, 122, 91-103. [CrossRef]

10. Onianwa, P.C. Monitoring atmospheric metal pollution: A review of the use of mosses as indicators. Environ. Monit. Assess. 2001, 71, 13-50. [CrossRef] [PubMed]

11. Goodman, G.T.; Roberts, T.M. Plants and soils as indicators of metals in the air. Nature 1971, 231, $287-292$. [CrossRef] [PubMed]

12. Cameron, A.J.; Nickless, G. Use of msses as collectors of airborne heavy metals near a smelting complex. Water Air Soil Pollut. 1977, 7, 117-125. [CrossRef]

13. Salo, H.; Berisha, A.; Makinen, J. Seasonal comparison of moss bag technique against vertical snow samples for monitoring atmospheric pollution. J. Environ. Sci. 2016, 41, 128-137. [CrossRef] [PubMed]

14. Viskari, E.L.; Rekila, R.; Roy, S.; Lehto, O.; Ruuskanen, J.; Karenlampi, L. Airborne pollutants along a roadside: Assessment using snow analyses and moss bags. Environ. Pollut. 1997, 97, 153-160. [CrossRef]

15. Salo, H.; Paturi, P.; Makinen, J. Moss bag (Sphagnum papillosum) magnetic and elemental properties for characterising seasonal and spatial variation in urban pollution. Int. J. Environ. Technol. 2016, 13, 1515-1524. [CrossRef]

16. Makholm, M.M.; Mladenoff, D.J. Efficacy of a biomonitoring (moss bag) technique for determining element deposition trends on a mid-range $(375 \mathrm{~km})$ scale. Environ. Monit. Assess. 2005, 104, 1-18. [CrossRef] [PubMed]

17. Culicov, O.A.; Yurukova, L. Comparison of element accumulation of different moss and lichen-bags, exposed in the city of Sofia (Bulgaria). J. Atmos. Chem. 2006, 55, 1-12. [CrossRef]

18. Adamo, P.; Bargagli, R.; Giordano, S.; Modenesi, P.; Monaci, F.; Pittao, E.; Spagnuolo, V.; Tretiach, M. Natural and pre-treatments induced variability in the chemical composition and morphology of lichens and mosses selected for active monitoring of airborne elements. Environ. Pollut. 2008, 152, 11-19. [CrossRef] [PubMed]

19. Capozzi, F.; Giordano, S.; Di Palma, A.; Spagnuolo, V.; De Nicola, F.; Adamo, P. Biomonitoring of atmospheric pollution by moss bags: Discriminating urban-rural structure in a fragmented landscape. Chemosphere 2016, 149, 211-218. [CrossRef] [PubMed]

20. Demkova, L.; Baranova, B.; Obona, J.; Arvay, J.; Losak, T. Assessment of air pollution by toxic elements on petrol stations using moss and lichen bag technique. Plant Soil Environ. 2017, 63, 355-361.

21. Modzelewska, D.; Do Hañczuk-Oeródka, A.; Ziembik, Z. Assessment of air contamination with selected radioisotopes nearby cement plant using moss bag method. Ecol. Chem. Eng. 2015, 22, 447-455. 
22. Milicevic, T.; Urosevic, M.A.; Vukovic, G.; Skrivanj, S.; Relic, D.; Frontasyeva, M.V.; Popovic, A. Assessment of species-specific and temporal variations of major, trace and rare earth elements in vineyard ambient using moss bags. Ecotoxicol. Environ. Saf. 2017, 144, 208-215. [CrossRef] [PubMed]

23. Vukovic, G.; Urosevic, M.A.; Skrivanj, S.; Milicevic, T.; Dimitrijevic, D.; Tomasevic, M.; Popovic, A. Moss bag biomonitoring of airborne toxic element decrease on a small scale: A street study in Belgrade, Serbia. Sci. Total Environ. 2016, 542, 394-403. [CrossRef] [PubMed]

24. Vuković, G.; Urošević, M.A.; Pergal, M.; Janković, M.; Goryainova, Z.; Tomašević, M.; Popović, A. Residential heating contribution to level of air pollutants (PAHs, major, trace, and rare earth elements): A moss bag case study. Environ. Sci. Pollut. Res. 2015, 22, 18956-18966. [CrossRef] [PubMed]

25. Urosevic, M.A.; Vukovic, G.; Jovanovic, P.; Vujicic, M.; Sabovljevic, A.; Sabovljevic, M.; Tomasevic, M. Urban background of air pollution: Evaluation through moss bag biomonitoring of trace elements in Botanical garden. Urban For. Urban Green. 2017, 25, 1-10. [CrossRef]

26. Harmens, H.; Norris, D.A.; Sharps, K.; Mills, G.; Alber, R.; Aleksiayenak, Y.; Blum, O.; Cucu-Man, S.M.; De Temmermang, L.; Ene, A.; et al. Heavy metal and nitrogen concentrations in mosses are declining across Europe whilst some "hotspots" remain in 2010. Environ. Pollut. 2015, 200, 93-104. [CrossRef] [PubMed]

27. Harmens, H.; Norris, D.A.; Koerber, G.R.; Buse, A.; Steinnes, E.; Ruehling, A. Temporal trends (1990-2000) in the concentration of cadmium, lead and mercury in mosses across Europe. Environ. Pollut. 2008, 151, 368-376. [CrossRef] [PubMed]

28. Harmens, H.; Norris, D.A.; Koerber, G.R.; Buse, A.; Steinnes, E.; Ruhling, A. Temporal trends in the concentration of arsenic, chromium, copper, iron, nickel, vanadium and zinc in mosses across Europe. Atmos. Environ. 2007, 41, 6673-6687. [CrossRef]

29. Cao, T.; Wang, M.; An, L.; Yu, Y.; Lou, Y.; Guo, S.; Zuo, B.; Liu, Y.; Wu, J.; Cao, Y.; et al. Air quality for metals and sulfur in Shanghai, China, determined with moss bags. Environ. Pollut. 2009, 4, 1270-1278. [CrossRef] [PubMed]

30. Sun, S.Q.; Wang, D.Y.; Ming, H.; Zhang, C. Monitoring of atmospheric heavy metal deposition in Chongqing, China-based on moss bag technique. Environ. Monit. Assess. 2009, 148, 1-9. [CrossRef] [PubMed]

31. Xie, F.; Tan, H.; Yang, B.; He, J.L.; Chen, A.N.; Wen, X.M. The study of atmospheric transport and deposition of cadmium emitted from primitive zinc production area. Water Air Soil Pollut. 2014, 225, 2162. [CrossRef]

32. Calabrese, S.; D'Alessandro, W.; Bellomo, S.; Brusca, L.; Martin, R.S.; Saiano, F.; Parello, F. Characterization of the Etna volcanic emissions through an active biomonitoring technique (moss-bags): Part 1-Major and trace element composition. Chemosphere 2015, 119, 1447. [CrossRef] [PubMed]

33. Vuković, G.; Aničić, U.M.; Razumenić, I.; Goryainova, Z.; Frontasyeva, M.; Tomašević, M.; Popović, A. Active moss biomonitoring of small-scale spatial distribution of airborne major and trace elements in the Belgrade urban area. Environ. Sci. Pollut. 2013, 20, 5461-5470. [CrossRef] [PubMed]

34. Vukovic, G.; Urosevic, M.A.; Skrivanj, S.; Vergel, K.; Tomasevic, M.; Popovic, A. The first survey of airborne trace elements at airport using moss bag technique. Environ. Sci. Pollut. 2017, 24, 15107-15115. [CrossRef] [PubMed]

35. Cesa, M.; Bertossi, A.; Cherubini, G.; Gava, E.; Mazzilis, D.; Piccoli, E.; Verardo, P.; Nimis, P.L. Development of a standard protocol for monitoring trace elements in continental waters with moss bags: inter- and intraspecific differences. Environ. Sci. Pollut. Res. 2015, 22, 5030-5040. [CrossRef] [PubMed]

36. Gecheva, G.; Yurukova, L. Water pollutant monitoring with aquatic bryophytes: A review. Environ. Chem. Lett. 2014, 12, 49-61. [CrossRef]

37. Zhou, X.; Chen, Q.; Liu, C.; Fang, Y. Using moss to assess airborne heavy metal pollution in Taizhou, China. Int. J. Environ. Res. Public Health 2017, 14, 403. [CrossRef] [PubMed]

38. Ma, Y.L.; Jia, G.M.; Wang, Y.P.; Liu, H.P. Contents of heavy metal in leaves of plants and air pollution evaluation in Guangzhou region. Urban Environ. Urban Ecol. 2001, 14, 28-30.

39. Kusunoki, K.; Sakata, M.; Tani, Y.; Seike, Y.; Ayukawa, K. Evaluating the contribution of long-range transport of heavy metals from the Asian continent to their concentrations in sediment cores from Lake Shiji, Western Japan. Water Air Soil Pollut. 2012, 223, 1151-1160. [CrossRef]

40. Tretiach, M.; Adamo, P.; Bargagli, R.; Baruffo, L.; Carletti, L.; Crisafulli, P.; Giordano, S.; Modenesi, P.; Orlando, S.; Pittao, E. Lichen and moss bags as monitoring devices in urban areas. Part I: Influence of exposure on sample vitality. Environ. Pollut. 2007, 146, 380-391. [CrossRef] [PubMed] 
41. Vuković, G.; Urošević, M.A.; Goryainova, Z.; Pergal, M.; Škrivanj, S.; Samson, R.; Popović, A. Active moss biomonitoring for extensive screening of urban air pollution: Magnetic and chemical analyses. Sci. Total Environ. 2015, 521, 200-210. [CrossRef] [PubMed]

42. Guttormsen, G. The content of lead, cadmium and PAH in vegetables and strawberries alongside the E18 motorway. Norsk Landbruksforsking 1993, 7, 175-189.

43. Song, F.; Gao, Y. Size distributions of trace elements associated with ambient particular matter in the affinity of a major highway in the New Jersey-New York metropolitan area. Atmos. Environ. 2011, 45, 6714-6723. [CrossRef]

44. Pakkanen, T.A.; Kerminen, V.M.; Loukkola, K.R.; Hillamo, E.; Aarnio, P.; Koskentalo, T.; Maenhaut, W. Size distributions of mass and chemical components in street-level and rooftop PM1 particles in Helsinki. Atmos. Environ. 2003, 37, 1673-1690. [CrossRef]

45. Al-Momani, I.F. Trace elements in atmospheric precipitation at Northern Jordan measured by ICP-MS: Acidity and possible sources. Atmos. Environ. 2003, 37, 4507-4515. [CrossRef]

46. Napier, F.; D'Arcy, B.; Jefferies, C. A review of vehicle related metals and polycyclic aromatic hydrocarbons in the UK environment. Desalination 2008, 226, 143-150. [CrossRef]

47. Capozzi, F.; Adamo, P.; Di Palma, A.; Aboal, J.R.; Bargagli, R.; Fernandez, J.A.; Lopez Mahia, P.; Reski, R.; Tretiach, M.; Spagnuolo, V.; et al. Sphagnum palustre clone vs native Pseudoscleropodium purum: A first trial in the field to validate the future of the moss bag technique. Environ. Pollut. 2017, 225, 323-328. [CrossRef] [PubMed]

(C) 2018 by the authors. Licensee MDPI, Basel, Switzerland. This article is an open access article distributed under the terms and conditions of the Creative Commons Attribution (CC BY) license (http:/ / creativecommons.org/licenses/by/4.0/). 